\title{
PERFORMATIVITAS DAN KOMODIFIKASI ANDROGINI DI MEDIA SOSIAL
}

\section{PERFORMATIVITY AND COMODIFICATION OF ANDROGYNE IN SOCIAL MEDIA}

\author{
${ }^{1}$ Selly Astari Octaviani, Ratna Noviani \\ Program Studi Kajian Budaya dan Media, Sekolah Pascasarjana, Universitas Gadjah Mada, \\ Yogyakarta
}

Submitted: 23-04-2021; Revised: 05-08-2021 Accepted: 12-08-2021

\begin{abstract}
The fluidity of social media allows gender identity that contrasts with conventional gender -- as Jovi and Anastasia have done through their androgynous identity -- exist. However, the identity represented in social media was not only intented as a form of self-expression; it also presents other interest. Based on this, this study aims to see how the performativity of Jovi and Anastasia's androgynous identity constructed in social media, and the role of the cultural industry that was involved. The analysis was carried out using the multimodality discourse analysis from Gunther Kress and Theo van Leeuwen, Judith Butler's concept of performativity, and the concept of self-representation in social media from Jill Walker Rettberg. Meanwhile, the corpus of this study is 4 photos consisting of 1 self portrait photo and 1 work photo, each of which has been uploaded by Jovi and Anastasia on their Instagram account. The result of this study found the performativity of androgynous identity that Jovi and Anastasia have done, not just self-expression, but also commodification practice. The tendency of Jovi and Anastasia performativity on one gender polar is a form of selfbranding that is part of the implemented marketing strategy.
\end{abstract}

Keywords: Androgynous; Performativity; Identity; Commodification.

\begin{abstract}
ABSTRAK
Fluiditas media sosial memungkinkan identitas gender yang berseberangan dengan gender konvensional seperti dilakukan Jovi dan Anastasia melalui identitas androgini. Namun demikian, performativitas identitas yang direpresentasikan di media sosial tidak hanya diperuntukkan sebagai ekspresi diri, melainkan juga ada kepentingan lain yang dihadirkan. Berdasarkan hal itu, kajian ini bertujuan untuk mengetahui bagaimana performativitas identitas androgini Jovi dan Anastasia di Instagram, dan bagaimana peran industri budaya dilibatkan. Analisis dilakukan dengan menggunakan analisis wacana multimodalitas dari Gunther Kress dan Theo van Leeuwen, konsep performativitas Judith Butler, dan konsep representasi diri di media sosial dari Jill Walker Rettberg. Adapun, korpus kajian ini ialah 4 foto yang terdiri dari 1 foto self-portrait dan 1 foto kerja yang masing-masing diunggah oleh Jovi serta Anastasia di akun Instagramnya. Hasil kajian memperlihatkan bahwa performativitas identitas androgini yang dilakukan keduanya bukan semata ekspresi diri, melainkan praktik komodifikasi. Kecenderungan performativitas Jovi dan Anastasia pada satu polar gender juga merupakan bentuk selfbranding yang menjadi bagian dari strategi pemasaran yang dijalankan.
\end{abstract}

Kata kunci: Androgini; Performativitas; Identitas; Komodifikasi.

*Corresponding author: octaselly10@gmail.com

Copyright@ 2021 Selly Astari Octaviani dan Dr. Ratna Noviani SIP., M.Si (S). This article is distributed under a Creative Commons Attribution-Share Alike

4.0 International license. Jurnal Kawistara is published by the Graduate School of Universitas Gadjah Mada. 


\section{PENGANTAR}

Pada era digital, media sosial dianggap menjadi ruang yang tepat bagi masyarakat untuk mengekspresikan dirinya secara 'bebas'. Pasalnya, fluiditas yang ditawarkan media sosial, memungkinkan para penggunanya untuk mengonstruksi identitas sesuai kepentingannya, termasuk identitas gender. Sebagai salah satu media sosial yang mengakomodasi ekspresi diri masyarakat, Instagram, memungkinkan penggunanya mengonstruksi identitas yang berlawanan dengan norma gender konvensional, terlihat dari hadirnya para androginus.

Berdasarkan pernyataan psikolog Sandra L. Bem, dalam artikelnya yang berjudul The Measurement of Psychological Androgyny (1974), androginus merupakan orang yang mengombinasikan penanda feminin dan maskulin pada tubuhnya, dan bergerak dinamis atas dua polar tersebut. Hal yang berbeda dari norma gender konvensional pelekatan femininitas hanya pada perempuan dan maskulinitas pada laki-laki.

Para androginus memanfaatkan visualitas di dalam Instagram untuk melakukan performativitas identitasnya melalui penandaan jasmani. Seperti dilakukan oleh lifestyle influencer, content creator, serta salah satu pemilik POUR clothing line, Jovi Adhiguna, dan seorang model dari agensi Jim Models, Anastasia Lie, yang memanfaatkan beragam atribut dan pengelolaan tubuh untuk melakukan performativitas identitas androgini di akun Instagramnya. Dalam hal ini, Jovi, mengandalkan penggunaan makeup, rambut panjang, aksesoris, dan beragam atribut feminin dan maskulin untuk menggambarkan keandroginiannya. Sementara, Anastasia tampak mengandalkan rambut pendek, ekspresi santai dan dingin, dan atribut unisex hingga maskulin.

Penanda-penanda andalan keduanya ini menunjukkan bahwa ada pengadopsian dan represi penanda feminin dan maskulin tertentu, dari kategorisasi yang didasarkan pada standar gender konvensional. Jovi yang berjenis kelamin laki-laki tampak merepresi beberapa penanda maskulin, seperti menghindari potongan rambut pendek, dan cenderung mengadopsi penanda-penanda feminin, seperti rambut panjang dan makeup. Hal serupa dilakukan Anastasia yang berjenis kelamin perempuan. Ia cenderung mengadopsi penanda maskulin tertentu, seperti berambut pendek serta menunjukkan ekspresi dingin, dan merepresi penanda feminin, seperti tidak mengenakan banyak makeup. Tindakan keduanya ini menunjukkan salah satu kunci performativitas yang dikatakan Judith Butler dalam bukunya Gender Trouble, yakni tindakan pengutipan atas konvensi tertentu (Butler, 1999: 178).

Merujuk pada penanda yang diandalkan Jovi dan Anastasia, tampak bahwa fashion menjadi ruang dan moda penting yang memungkinkan keduanya mengekspresikan keandroginiannya secara 'bebas'. Elizabeth Wilson dalam bukunya Adorened in Dreams: Fashion and Modernity, menuliskan bahwa fashion mendefinisikan ulang batas gender (Wilson, 2003:117). Namun demikian, dalam mendefinisikan sesuatu, industri fashion memiliki standarisasi tersendiri. Dengan kata lain, ketika menggunakan fashion, Jovi dan Anastasia tidak sepenuhnya bebas ketika berekspresi. Secara sadar atau tidak, standarisasi pihak industri mengatur Jovi dan Anastasia saat mengekspresikan dirinya, diantaranya melalui pembentukan tubuh maupun seleksi pengadopsian penandapenanda tertentu.

Selain itu, fashion juga membuka ruangruang lain yang memungkinkan androginus mengekspresikan dirinya secara 'bebas', salah satunya ialah media sosial. Media sosial yang bersifat fleksibel melalui beragam fitur yang disediakannya, memberikan keleluasaan kepada para androginus untuk berekspresi. Namun demikian, sebagaimana fashion, media sosial juga memiliki kepentingannya sendiri dalam menampilkan sesuatu. Penggunaan fashion dan media sosial oleh Jovi dan Anastasia ini menunjukkan bahwa dalam melakukan performativitas identitas androgini, keduanya tidak dapat lepas dari 
produk dan praktik industri budaya. Dengan kata lain, kedua industri ini juga memiliki peran dalam membangun performativitas keduanya. Berdasarkan dari latar belakang tersebut menjadi menarik bagi peneliti untuk mengkaji bagaimana performativitas androgini yang dilakukan Jovi dan Anastasia di akun Instagramnya. Lalu, apa saja industri budaya yang dilibatkan serta bagaimana perannya? Kajian ini diharapkan dapat menjadi literatur yang membantu dalam kajian performativitas androgini dan kaitannya dengan industri budaya yang dilibatkan.

Kajian ini dilakukan dengan menggunakan metode analisis wacana multimodalitas dari Gunther Kress dan Theo van Leeuwen. Metode ini digunakan untuk melihat apa saja moda yang digunakan, bagaimana moda tersebut dipilih, dan bagaimana peran dari moda tersebut dalam performativitas yang dilakukan Jovi dan Anastasia di Instagram. Melalui berbagai fitur yang ditawarkan media sosial, seseorang tidak hanya mengandalkan moda teks sebagai alatnya, melainkan juga berbagai moda semiotik yang berbeda, seperti foto, layout, dan lainnya. Penelitian ini juga menggunakan konsep performativity dari Judith Butler (1999) untuk melihat secara detail bagaimana identitas androgini dibangun melalui performativitas. Dipadu dengan konsep self-representation in social media dari Jill Walker Rettberg (2017), kedua konsep ini digunakan untuk melihat kepentingan lain yang berupaya dicapai melalui unggahan representasi diri Jovi dan Anastasia di akun Instagramnya masingmasing dan bagaimana kaitannya dengan performativitas yang dilakukan.

Objek pada kajian ini adalah konten yang diunggah Jovi dan Anastasia di akun Instagramnya masing-masing. Berupa 4 foto yang terdiri dari 2 foto Jovi (self portrait, dan foto kerja) serta 2 foto Anastasia (self portrait, dan foto kerja) yang diunggah pada periode Juli-Desember 2018. Pemilihan foto tersebut didasarkan pada beberapa indikator pertimbangan, diantaranya representasi diri, ketubuhan, dan preferensi selera.

\section{PEMBAHASAN \\ Konstruksi Identitas melalui Performativitas}

Kajian ini bertitik tolak dari pernyataan Judith Butler (1999) bahwa identitas bukanlah sesuatu yang telah ada secara biologis, melainkan dikonstruksi secara kultural. Bagi Butler, identitas dan peran gender, seperti femininitas dan maskulinitas, merupakan hal yang dibangun dari tindakan yang secara aktif dilakukan seseorang yang dikenal dengan sebutan performativitas. Hal ini berangkat dari pemahaman Butler bahwa identifikasi gender berasal dari fantasi yang dibuat melalui penandaan jasmani (Butler, 1999: 174). Adapun penandaan di sini berkaitan dengan atribut, perilaku, serta tindakan lainnya yang dilekatkan pada jasmaninya.

Namun demikian, setiap atribut yang dilibatkan pun bukanlah hal yang baru, melainkan berupa pengutipan dan pengulangan sejumlah norma dan konvensi yang ada (Barker, 2014: 203). Misalnya, mengadopsi atribut penanda tertentu, bertindak dan berbicara yang mengesankan laki-laki atau perempuan sesuai budaya tertentu secara berulang. Pada akhirnya, dapat dikatakan bahwa identitas gender bukanlah hal yang stabil, melainkan cair dan dapat diubah melalui penandaan kembali dan rekonstekstualisasi. Hal ini menegaskan pendapat Butler bahwa sejak awal, seseorang tidak memiliki gender 'asli' (Butler, 1999: 33). Melalui konsep performativitas ini, Butler menegaskan bahwa identitas dapat diubah seiring dengan perubahan penandaan jasmani pada tubuh seseorang yang diperbaharui, direvisi, dan dikonsolidasikan secara berulang dalam kurun waktu tertentu (Butler, 1988: 523). Dengan kata lain, seseorang dapat mengubah identitas gendernya sesuai dengan apa yang ia imajinasikan.

Akan tetapi, tidak sebatas proses konstruksi identitas, performativitas gender juga memperlihatkan interpretasi individu dan situasi tertentu di lingkungan sekitarnya. Pada praktiknya, performativitas gender yang dilakukan juga menunjukkan tindakan seseorang 
dalam menjaga atau mendekonstruksi peran dan relasi gender yang telah disepakati secara sosial dalam konteks ruang dan waktu tertentu.

\section{Representasi Diri di Media Sosial}

Tindakan performativitas memiliki hubungan yang erat dengan representasi. Sebagaimana diketahui, representasi merupakan sebuah produksi makna atas konsep yang ada di dalam pikiran seseorang yang disampaikan melalui bahasa (Hall, 1997: 17). Melalui representasinya, seseorang berupaya mengatakan atau menghadirkan sesuatu. Tidak sekedar menginformasikan, representasi di sini berkaitan dengan persoalan kekuasaan yang seringkali ditegaskan secara implisit. Dengan menggunakan bahasa, seseorang "menghidupkan" sejumlah pengetahuan dan "mematikan" sejumlah pengetahuan lainnya (Barker, 2014:255). Dengan kata lain, representasi diri dipandang sebagai sesuatu yang politis, ia dapat memiliki makna yang berbeda dari apa yang terlihat.

Pada era digital, banyak orang memilih media sosial untuk menjadi ruang yang mewadahi representasi dirinya. Instagram merupakan salah satu media sosial yang sering digunakan masyarakat untuk merepresentasikan dirinya. Sifat cair dan berbagai fitur pada platform ini dianggap mampu mendukung representasi diri yang diinginkan penggunanya. Menurut Profesor Budaya Digital di Universitas Bergen, Norwegia sekaligus Peneliti utama Proyek ERC Machine Vision: Machine Vision in Everyday Life: Playful Interactions with Visual Technologies in Digital Art, Games, Narratives and Social Media, Jill Walker Rettberg, ada tiga moda representasi diri dalam Instagram yang dapat digunakan para penggunanya, yakni tulisan, visual, dan kuantitatif (Rettberg, 2014: 1).

Moda representasi tulisan berkaitan dengan teks yang digunakan dalam media sosial, seperti caption, teks dalam foto atau instastory, dan komentar. Dalam moda ini, kata diolah sedemikian rupa untuk mengonstruksi identitas, membangun hubungan dengan audiens, dan lainnya. Kemudian, moda representasi visual berkaitan dengan gambar atau ikon yang digunakan pada foto maupun teks. Pada praktiknya, moda ini dipandang tidak semata menampilkan identitas diri yang diimajinasikan, tetapi juga menggambarkan konektivitas antara tubuh dengan suatu hal (Warfield dalam Rettberg, 2017:17). Konektivitas tersebut juga tidak dibangun secara netral. Praktik dan konteks representasi diri tertentu dapat memungkinkan seseorang membentuk relasi kuasa atas wacana tertentu, sebagai gambar tersebut diposisikan (Cruz dan Thornham, 2015:3).

Selanjutnya, moda representasi kuantitatif berkaitan dengan rekaman aktivitas pengguna yang ditampilkan melalui angka dan grafik ketika menggunakan media sosial. Hal ini terlihat melalui jumlah likes pada foto atau gambar atau views pada video. Moda representasi yang satu ini dibangun dengan keyakinan bahwa pengetahuan terkait selftracking atau algoritma dari aktivitas pengguna dapat meningkatkan citra diri seseorang. Berbekal pengetahuan dari self-tracking ini, pengguna dapat menegosiasikan datanya untuk menampilkan representasi diri yang sesuai dengan imajinasinya (Rettberg, 2017:23).

Tidak semata menampilkan konstruksi citra diri yang 'ideal', ketiga moda representasi diri ini juga dimanfaatkan untuk memperoleh nilai tertentu. Sebagaimana ditegaskan oleh Cruz dan Thornham, praktik representasi diri dirancang dan diproduksi dalam struktur kuasa yang secara bersamaan menjalankan nilai tertentu di dalamnya (Cruz dan Thornham, 2015:7). Misalnya, nilai ekonomi yang dikejar para influencer di Instagram. Untuk memperoleh nilai tersebut, seseorang cenderung melakukan proses seleksi atas representasi diri yang akan ditampilkan atau dikenal dengan sebutan filter. Ada tiga bentuk filter yang biasanya dilakukan dalam praktik representasi diri di Instagram, yakni filter teknologi, filter budaya, dan filter kognitif (Rettberg, 2014: 20).

Akan tetapi, ketika menggunakan modamoda di Instagram ini, pengguna tidak dipandang sebagai diri yang otonom. Berbagai fitur yang tersedia di dalam Instagram itu sendiri berperan besar dalam pembentukan representasi diri seseorang. Dengan kata lain, pengguna hanya memperoleh sense of freedom dari Instagram, bukan kebebasan yang sesungguhnya. 


\section{Identifikasi Gender Androgini Melalui Self Portrait}

Dalam konsep androgini, seseorang dapat memadukan penanda feminin dan maskulin dalam satu tubuh dan bergerak dinamis antara dua polar tersebut. Performativitas Jovi dan Anastasia sebagai androginus memperlihatkan kompleksitas ekspresi gender yang tidak dapat diwakili oleh satu polar gender sebagaimana norma gender konvensional. Meski berangkat dari konsep androgini yang serupa, menariknya, Jovi dan Anastasia melakukan performativitas identitas gendernya ini dengan cara yang berbeda. Terlihat dari seleksi atribut serta gesture yang ditonjolkan dan dikaburkan keduanya ketika mengonstruksi identitas androgini. Meski begitu, ruang di Instagram tetap ikut 'mendikte' Jovi dan Anastasia yang mau tidak mau, diikuti keduanya melalui penyesuaian diri dengan medialitas Instagram.

Salah satunya terlihat dari unggahan berbentuk self-portrait. Pengambilan gambar yang dilakukan dengan cara medium long shot dan long shot, 'menuntut' keduanya untuk menunjukkan keandroginiannya dari jarak jauh. Namun, di saat bersamaan, teknik ini memungkinkan keduanya memaksimalkan penandaan jasmani pada seluruh tubuhnya untuk melakukan performativitas identitas androgininya. Hal ini dikarenakan, teknik ini memungkinkan penampilan keduanya terlihat dari ujung kepala hingga ujung kaki.

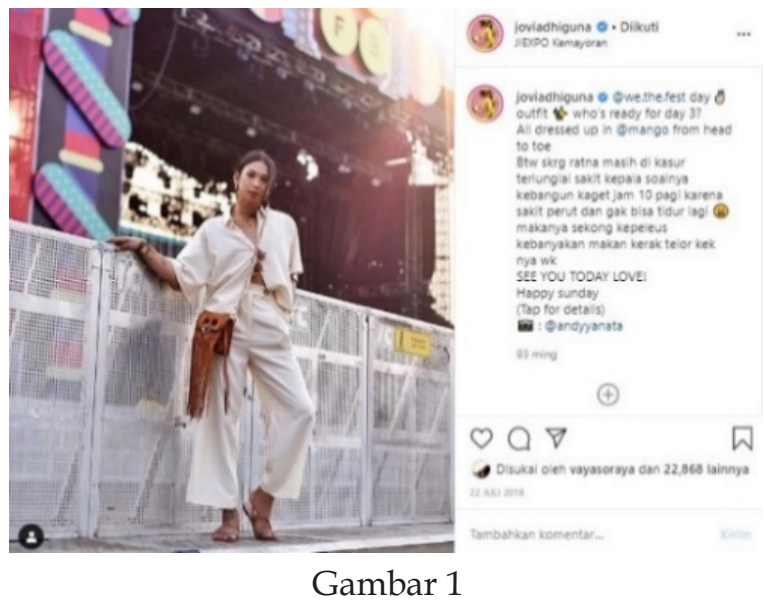

Self-portrait Jovi Adhiguna (2018) Sumber: Instagram @joviadhiguna.

\begin{abstract}
“@we.the fest day (emoticon peace) outfit (emoticon blink) who's ready for day 3? All dressed up in @mango from head to toe. Btw skrg ratna masih di kasur terlunglai sakit kepala soalnya kebangun kaget jam 10 pagi karena sakit perut dan gak bisa tidur lagi (emoticon sad) makanya sekong kepeleus kebanyakan makan kerak telor kek nya wk. SEE YOU TODAY LOVE! Happy sunday. (Tap for details). (emoticon kamera): @andyyanata".
\end{abstract}

Seperti terlihat pada self-portrait Jovi di gambar 1. Jovi tampak memfokuskan pemilihan atribut serta gesture yang dapat segera dikenali dari jarak jauh untuk mengonstruksi identitas androgininya. Jovi terlihat merepresi maskulinitas yang diperlihatkan melalui bentuk tubuhnya, dengan mendominasi tubuh menggunakan berbagai jenis atribut dan gesture, hingga padanan caption yang memperlihatkan femininitas.

Makeup tampak menjadi salah satu atribut feminin andalannya, terlihat dari bagaimana ia merepetisi penggunaannya pada seluruh konten foto yang diunggah. Begitu pula dikenakan pada self-portrait-nya yang diperlihatkan pada gambar 1. Penanda feminin juga diperlihatkan Jovi melalui penggunaan berbagai aksesoris, seperti anting, kalung, cincin, gelang, dan kacamata berbentuk cat eyes. Pada busana, Jovi cenderung merepetisi busana dengan model v-neck. Seperti juga diperlihatkan pada gambar 1, ia memodifikasi penggunaan kemeja yang hanya dipasangkan satu kancing untuk menciptakan bentuk v-neck pada bagian atas dan bawah. Tujuannya untuk memperlihatkan bentuk dada dan pusar. Sebagaimana diketahui model v-neck ditujukan untuk memperlihatkan belahan payudara yang dianggap sebagai situs penting penanda femininitas, maternalitas dan seksualitas seseorang dalam hegemoni gender (Gina dan Sigiro, 2019: 222). Begitu pula bentuk pusar yang terlihat distereotipkan sebagai penanda femininitas yang seringkali dikaitkan dengan kesan seksi. Penanda feminin juga diperlihatkan Jovi melalui penggunaan kulot, hippie sling bag, dan strappy sandals. Begitu pula pada pemilihan warna, alih-alih memilih warna gelap dan netral, Jovi cenderung mendominasi atributnya dengan berbagai macam warna, 
termasuk pastel dan bold. Seperti pada busana di gambar 1, Jovi mengenakan warna khaki.

Di samping atribut, Jovi juga memodifikasi tubuhnya untuk menjadi penanda feminin. Terlihat dari rambut panjang yang diadopsi Jovi dan diperlihatkan secara repetitif pada seluruh kontennya. Hal ini menunjukkan, rambut panjang merupakan salah satu penanda feminin lainnya yang paling diandalkan Jovi.

Jovi juga mengadopsi berbagai gesture yang menandakan femininitas. Dalam hal ini, Jovi berfokus pada gesture yang membangun kesan seksi. Pada sebagian besar kontennya, kesan seksi dibangun Jovi melalui penonjolan permainan gerakan beberapa bagian tubuh, seperti jemari, pinggul, dan dadanya (Kurnia, 2004: 20). Gesture-gesture ini seringkali ia padukan dengan seductive gaze, seperti terlihat pada gambar 1. Jovi tampak menonjolkan dadanya ke satu sisi, dan pinggulnya ke sisi lainnya, ia juga memainkan jemarinya ketika memegang pagar pembatas, serta memadukannya dengan seductive gaze yang diarahkan langsung pada audiens.

Penanda feminin juga diperlihatkan Jovi melalui caption-nya. Salah satunya terlihat dari repetisi Jovi dalam menggunakan elemenelemen seperti emoticon yang ekspresif (love, kiss, cry, smile, dan lainnya) pada unggahannya. Sebagaimana stereotip, femininitas dikaitkan dengan sosok yang emosional dan peka terhadap perasaan. Femininitas Jovi juga terlihat dari repetisi penggunaan panggilan sayang kepada audiens (beb, love, say), memelesetkan kata (seperti sakit kepala menjadi sekong kepeleus pada gambar 1), dan panggilan baru untuk dirinya sendiri dengan nama yang distereotipkan sebagai nama perempuan, yakni "Ratna", yang ditunjukkan pada caption gambar 1 .

Di samping mendominasi tubuh dengan penanda feminin, Jovi juga memperlihatkan sisi maskulin pada performativitasnya. Memanfaatkan visualitas penuh daribentukselfportrait, Jovi memperlihatkan sisi maskulinnya melalui gesture. Terlihat pada gambar 1, Jovi mengadopsi gesture mengangkang yang menjadi andalan pada beberapa unggahannya di Instagram. Penanda maskulin lainnya diperlihatkan melalui modifikasi tubuh melalui penonjolan tato pada beberapa area tubuhnya, seperti pada tangan dan kaki di gambar 1 . Salah satu modifikasi tubuh ini diketahui mampu memberikan kesan maskulin dan dominan pada penggunanya, baik perempuan maupun laki-laki (Galbarcyzka, 2017:2). Ia juga memperlihatkan visualitas otot sebagai penanda maskulinnya. Dengan kata lain, Jovi tampak mengandalkan tubuhnya sebagai penanda maskulinitas.

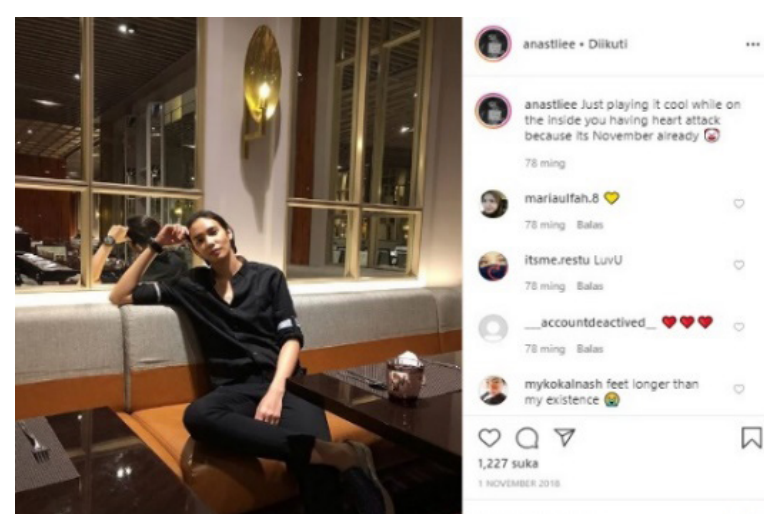

Gambar 2

Self-portrait Anastasia (2018)

Sumber: Instagram @anastlie.

"Just playing it cool while on the inside you having heart attack because its November already (emoticon clown)".

Berbeda dengan Jovi, Anastasia tampak melibatkan atribut dengan jumlah yang lebih minim dalam mengonstruksi identitas androgininya. Adapun, atribut-atribut yang melekat pada tubuhnya tersebut didominasi dengan karakter maskulin. Terlihat dari gambar 2, Anastasia mengenakan jam chronograph dengan strap stainless steel berukuran besar berwarna hitam, kemeja berukuran agak longgar dengan circle neck dan bagian lengan yang digulung berwarna senada, dan sepatu slip-on untuk menandakan maskulinitasnya. Kecenderungan Anastasia dalam memilih warna gelap dan corak yang polos pada atributnya ini membuat maskulinitasnya terlihat dengan jelas meski dari jarak jauh. Melalui atribut, Anastasia juga memperlihatkan femininitasnya melalui repetisi penggunaan 
anting, serta makeup tipis yang berfokus pada alis.

Sementara pada pengelolaan tubuh, Anastasia tetap berfokus pada polar maskulin. Terlihat dari potongan rambut pendek yang dipertahankannya pada seluruh unggahannya, sebagaimana juga diperlihatkan pada gambar 2. Gaya rambut pendek distereotipkan pada laki-laki dengan maskulinitasnya (Martin dan Macrae dalam Eyssel dan Hegel, 2012: 2215), sementara rambut panjang dilekatkan pada femininitas perempuan. Selain itu, memanfaatkan penggunaan atribut yang longgar, Anastasia juga tampak memanipulasi tubuhnya untuk merepresi femininitas pada dirinya dan mengalihkannya menjadi maskulin. Alih-alih menunjukkan bentuk payudara, Anastasia justru mengaburkan bentuknya dan menjadikannya tampak rata selayaknya dada laki-laki untuk menegaskan maskulinitasnya.

Anastasia juga mengadopsi beberapa gesture untuk menandakan maskulinitasnya. Diantaranya, cold stare, seperti terlihat pada gambar 2, dan tidak terlalu memperlihatkan ekspresi diri yang berkaitan dengan perasaannya. Gesture ini seringkali dipadukan Anastasia dengan gesture maskulin yang melibatkan tangan dan kakinya. Seperti terlihat pada gambar 2, kesan maskulin tampak pada paduan cold stare dengan gesture duduk mengangkang.

Berbeda dengan visualitasnya yang condong pada satu polar gender, yakni maskulin, pada caption Anastasia tampak memadukan dua polar gender untuk menunjukkan keandroginiannya. Terlihat dari penggunaan teks berisi quotes atau pesan tentang kehidupan sebagai penanda maskulin kompeten (Abele dan Wojciszke dalam Kollmayer dkk, 2018: 3), dan penggunaan emoticon sebagai penanda feminin (Fox dalam Sabater, 2017: 8). Cara penulisan caption ini direpetisi pada hampir seluruh unggahannya, terkecuali caption foto kerja.

Dari pemaparan ini dapat dilihat bahwa dalam melakukan performativitas identitas androgini, keduanya memperlihatkan kecenderungan yang berbeda. Melalui pengamatan atas pengadopsian atribut dan gesture pada unggahannya, Jovi Adhiguna tampak lebih condong pada polar gender feminin. Sebaliknya, Anastasia memperlihatkan performativitas yang condong pada polar gender maskulin.

\section{Deklarasi Fleksibilitas Androgini Melalui Negosiasi Diri}

Sebagaimana dikatakan sebelumnya, fashion memfasilitasi androginus dalam menunjukkan pergerakan dinamis antar polar gender melalui penggunaan atribut-atribut tertentu dan bagaimana hal itu ditampilkan. Hal ini kemudian membuat fashion tampak menjadi ruang yang 'bebas' bagi androginus untuk menunjukkan ekspresi dirinya. Namun demikian, fashion bukanlah media yang netral. Ia tidak sekedar memberi ruang pada androginus untuk berekspresi, tetapi juga memanfaatkan ekspresi diri tersebut untuk memperluas bisnisnya. Jovi dan Anastasia yang tampaknya menyadari strategi industri tersebut, melihatnya sebagai peluang untuk memperoleh keuntungan ekonomi juga. Terlihat dari bagaimana keduanya tampak menawarkan diri sebagai model yang mempromosikan dan memperkuat nilai komoditas yang dijual industri fashion tersebut. Dari hal ini dapat terlihat bahwa ada relasi bisnis yang terbentuk antara industri fashion dengan Jovi dan Anastasia. Dalam hal ini, mereka tampak berbagi keuntungan dari ruang tersebut.

Akan tetapi, sebagaimana industri budaya lainnya, fashion memiliki standarisasi tersendiri terhadap sosok yang akan merepresentasikan produknya. Ketika menggunakannya, Jovi dan Anastasia 'dipaksa' untuk menegosiasikan dirinya dan menyesuaikan diri dengan standarisasi yang telah ditentukan industri. Misalnya, ukuran tubuh keduanya disesuaikan dengan standar fashion yang digunakan, seleksi pengadopsian atribut mana yang dipandang feminin dan maskulin, hingga jumlah atribut dan gesture yang digunakan untuk mengonstruksi identitas androgini. Tak jarang, hal ini berbeda dengan ekspresi diri yang biasa ditampilkan keduanya. Terlihat dari beragam 
atribut dan gesture tubuh Jovi dan Anastasia pada unggahan foto kerjanya.

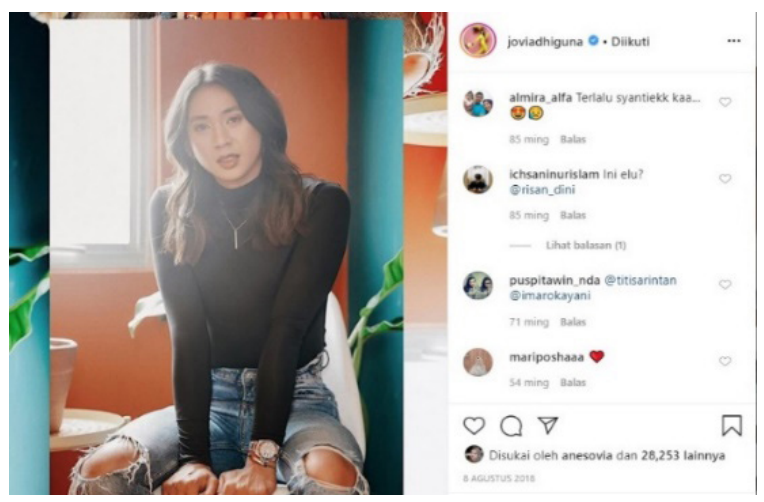

Gambar 3

Self Portrait Kerja Jovi Adhiguna (2018) Sumber: Instagram @joviadhiguna.

"My collaboration with @madedifferentco.id is finally out! (emoticon menangis dan love). We've worked so hard for this 3 pieces collection which consist necklace, bracelet, earrings yg aku kasih nama jessy (nama ibu suri) joy (nama almarhum papa) merzy (nama almarhum kakak aku) (emoticon love). I hope you guys love'em as much as I do. Make sure you guys check the full collection di@madedifferentco.id official website (emoticon menangis dan love). Would love to see all of you wearing them and tag me on Instagram (emoticon love). \#MadeDifferentCoXJoviAdhiguna. (emoticon kamera): @adityasurjana.Location: @ solandblues"

Tidak seperti self-portrait-nya, jenis dan jumlah atribut yang dikenakan Jovi tampak disesuaikan dengan produk yang dipromosikan. Seperti terlihat pada gambar 3, foto ini menunjukkan promosi produk aksesoris kolaborasi Jovi Adhiguna x Made Different co, produk yang diperuntukkan untuk dua polar gender. Jovi tidak mendominasi seluruh tubuhnya dengan atribut feminin seperti biasanya, ia justru membagi penampilannya menjadi dua zona terpisah untuk memperlihatkan keandroginian pada tubuhnya.

Pada zona tubuh bagian atas, atribut dan gesture lebih condong pada penanda feminin, terlihat dari modifikasi rambut panjang bergaya curly, makeup, serta gesture merapatkan kedua lengan bagian atas ke depan dada untuk menciptakan penonjolan siluet bentuk payudara pada gambar 3. Sebaliknya, pada zona tubuh bagian bawah, ia mengenakan rip jeans standard, dress watch dengan strap berukuran besar, serta visualisasi otot tubuh melalui busana turtle neck yang ketat. Begitu pula pada gesture, ia memperlihatkan pose mengangkang andalannya untuk menunjukkan maskulinitas.

Negosiasi diri atas standarisasi ekspresi androgini industri ini juga ditemukan pada sebagian besar unggahan foto kerjanya yang lain. Ia tidak lagi hanya mengandalkan tubuhnya sebagai penanda maskulin, di saat bersamaan, femininitasnya juga tidak diperlihatkan dalam pengadopsian atribut feminin yang tinggi sebagaimana banyak ditemukan pada unggahan foto kesehariannya. Negosiasi diri yang diperlihatkan Jovi melalui foto kerja ini, tampak digunakannya untuk menunjukkan fleksibilitas dirinya sebagai androgini. Di saat bersamaan, tindakannya ini juga memperlihatkan komodifikasi terhadap identitas androgininya sebagai identitas yang unik, 'bebas', dan dinamis sesuai kebutuhan masyarakat modern.

Sementara pada caption, Jovi tetap merepetisi penggunaan elemen-elemen feminin sebagaimana pada unggahan kesehariannya. Hal ini dilakukan untuk membangun kepercayaan dan intimacy dengan followers-nya. Mengingat, kepercayaan dan keintiman memainkan peran besar dalam hubungan influencer dengan audiens. Dalam hal ini, audiens cenderung terdorong untuk melakukan transaksi atau konsumsi ketika memperoleh informasi dari influencer bila ada aspek kepercayaan di antara keduanya (McCaskill dalam Cano, 2019: 14).

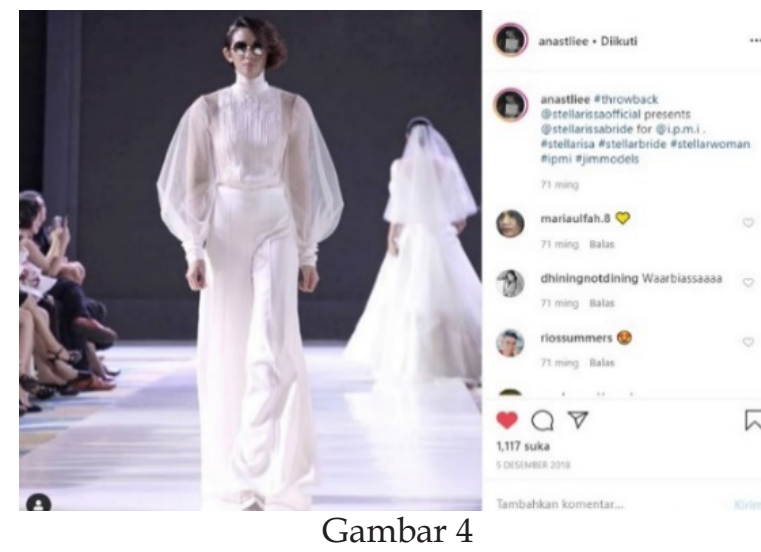

Self Portrait Foto Kerja Anastasia (2018)

Sumber: Instagram @anastlie 
"\#throwback@stellarissaofficial presents @stellarissabride for @i.p.m.i, \#stellarisa \#stellarbride \#stellarwoman \#ipmi \#jimmodels"

Negosiasi diri juga dilakukan oleh Anastasia yang tidak lagi mendominasi tubuhnya dengan atribut maskulin. Khususnya, ketika ia berjalan di atas catwalk, ia harus mengikuti rancangan desainer tertentu, seperti pada gambar 4. Meski begitu, sebagai model androgini, atribut yang dikenakan Anastasia tetap berbeda dengan model lainnya, khusunya ketika tema fashion show fokus pada atribut feminin. Di saat model lain didominasi atribut feminin, Anastasia tampil dengan rangkaian atribut yang femininitasnya telah direpresi. Seperti ditunjukkan pada gambar 4, yang menampilkan Anastasia dalam fashion show bertema pengantin perempuan.

Tidak seperti model lain yang mengenakan atribut feminin khas pengantin, yakni long veil dan dress atau gaun pengantin berenda, Anastasia justru tampil dengan wide leg pants dan blouse dengan balloon style pada bagian lengan. Ia juga tampil dengan atribut maskulin, seperti rambut pendek dan kacamata hitam. Pola yang serupa ditemukan pada sejumlah foto fashion show Anastasia.

Kombinasi penanda feminin dan maskulin juga ditemukan pada caption-nya. Alih-alih menuliskan quotes, Anastasia cenderung membuat caption yang singkat dan to the point untuk menandakan maskulinitasnya. Dengan menggunakan fitur mention dan hashtag, ia menyebutkan data berbagai pihak yang terlibat dalam fashion show maupun photoshoot yang dilakukannya, seperti makeup artist, desainer, acara yang diikutinya, dan lainnya. Seperti terlihat pada caption gambar 4, diantaranya, "@stellarissaofficial","@stellariss abride",“@i.p.m.i", “\#stellarisa", "\#stellarbride”," \#stellarwoman", "\#ipmi", dan agensinya sendiri "\#jimmodels". Sementara penanda feminin, diperlihatkannya melalui penggunaan emoticon yang mengekspresikan perasaannya atas momen terkait. Tindakan ini memperlihatkan gerakan dinamisnya antara dua polar gender sebagaimana konsep androgini.

Negosiasi terkait penggunaan atribut, gesture, hingga penulisan caption ini diterapkan secara halus melalui wacana ekspresi diri. Penampilan Jovi yang pada kesehariannya didominasi atribut feminin, tampil dengan pola yang beragam ketika berkaitan dengan promosi suatu produk. Begitu pula Anastasia yang condong pada polar gender maskulin pada kesehariannya, tampil berbeda ketika fashion show sesuai dengan rancangan dari desainer terkait. Fleksibilitas keduanya ini menunjukkan apa yang dikatakan Judith Butler bahwa gender bukanlah sesuatu yang stabil, melainkan dapat diubah. Namun demikian, performativitas seseorang juga tidak hanya berdasarkan dari pengetahuan tunggal orang terkait, melainkan ada konteks kultur dan relasi yang juga mempengaruhi konstruksi identitas tersebut (Butler, 1988:523). Terlihat dari bagaimana relasi Jovi dan Anastasia dengan pihak industri kemudian mempengaruhi dan membuat keduanya bernegosiasi atas performativitas yang dilakukannya. Berangkat dari sudut pandang teori feminis yang memandang konstruksi gender sebagai tindakan politis yang sengaja dikelola untuk tujuan yang lebih luas (Butler, 1988: 523), tindakan Jovi dan Anastasia ini dipandang tidak semata sebuah ekspresi diri. Keduanya memanfaatkan performativitas androgininya untuk meraih motif lain, yakni motif ekonomi.

\section{Self-Branding Sebagai Strategi Komodifikasi Androgini}

Kress dan van Leeuwen menyatakan, setiap moda semiotik bukanlah alat yang netral melainkan memiliki perannya tersendiri dalam mengartikulasikan dan menyebarkan wacanawacana tertentu (Kress dan van Leeuwen dalam Noviani, 2018: 120). Fashion, dalam hal ini, bukanlah media netral yang memberikan ruang kepada para penggunanya semata untuk mengekspresikan diri. Sebagai penyedia ruang, fashion juga memanfaatkan ekspresi diri tersebut untuk memperluas pemasarannya. Hal ini disadari oleh Jovi dan Anastasia yang kemudian menawarkan identitasnya untuk mencapai tujuan industri, sekaligus memperoleh keuntungan dari hal tersebut. Dalam hal ini, kedua pihak tampak berbagi keuntungan, Jovi dan Anastasia memperoleh 
ruang untuk berekspresi sekaligus memperoleh keuntungan ekonomi dari ruang tersebut, dan industri dapat memperluas pemasarannya.

Performativitas androgini yang dibangun keduanya bukan sekedar sebagai ekspresi diri, melainkan strategi keduanya dalam membangun self-branding. Self-branding sendiri merupakan sebuah tindakan yang dilakukan seseorang untuk mengembangkan citra diri yang berbeda dari orang lain untuk memperoleh keuntungan ekonomi dan modal kultural (Khakis, Ang dan Welling dalam Cano, 2019: 10). Dalam hal ini, identitas androgini yang berseberangan dengan gender konvensional dikonstruksi sebagai identitas 'unik' yang dianggap memenuhi kebutuhan masyarakat di era digital untuk menjadi berbeda dari individu lainnya.

Pada praktiknya, self-branding dilakukan untuk meningkatkan jumlah followers yang selanjutnya digunakan untuk menarik perhatian serta membangun mutual relationship dengan industri tertentu. Jovi dan Anastasia dalam hal ini menggunakan performativitas identitas androgini yang diklaim telah dilakukan keduanya sejak kecil secara konsisten hingga saat ini sebagai strategi self brandingnya. Melalui penerapan strategi ini secara konsisten, Jovi kini telah memperoleh followers sebanyak $752 \mathrm{~K}$ sejak unggahan pertamanya pada 10 April 2015. Sementara, Anastasia yang pertama kali mengunggah fotonya pada 3 Desember 2013, hingga kini telah memperoleh followers sebanyak 29.9K.

Tak sekedar identitas androgini, keduanya menjadikan kecenderungan performativitas identitasnya pada satu polar gender ini sebagai strategi konstruksi self-branding-nya. Dalam hal ini, tampak ada dua motif ekonomi yang dikejar Jovi melalui performativitasnya, yakni memperoleh kerja sama endorsement dan memperluas self-branding-nya melalui citra perusahaan yang bekerjasama dengan dirinya.

Pada praktiknya, Jovi memanfaatkan fitur tag, hashtag, dan mention brand-brand terkait untuk memperoleh motif ekonomi ini. Seperti diperlihatkan pada gambar 1 beserta captionnya, Jovi mengenakan busana yang berasal dari Mango juga menggunakan fitur mentions yang dihubungkan pada "@mango" untuk mempromosikan produk sekaligus brandnya. Citra Mango sebagai perusahaan fashion ternama juga secara bersamaan meningkatkan kualitas Jovi sebagai influencer terpercaya terkait fashion style. Kemudian, mention nama acara "@we.the.fest", meningkatkan citra Jovi sebagai sosok yang penting, selalu up to date, dan kekinian. Hal ini dapat meningkatkan kepercayaan audiens terhadap selera dan opininya terhadap fashion style terkini. Lalu, mentions terhadap “@andyyanata” juga memiliki tujuan serupa dengan mentions pada brand @ mango. Jovi mempromosikan jasa fotografinya, sekaligus meningkatkan citra dirinya yang bekerja sama dengan fotografer profesional. Seluruh tujuan ini pun dipertegas Jovi melalui penggunaan fitur tag yang menghubungkan foto tersebut langsung ke akun Instagram brand terkait, terlihat dari keterangan "tap for details" pada caption.

Untuk memperkuat self-branding ini, Jovi tampak mengutamakan pembentukan hubungan yang intim antara dirinya dengan followers. Terlihat dari seluruh moda yang digunakan dalam unggahannya, mulai dari shot, angle, gaze, dan penulisan caption.

Seperti terlihat pada gambar 1, keintiman dibangun melalui tatapan yang diarahkan langsung pada audiens, penulisan caption yang memposisikan followers dalam hubungan intim dengan Jovi. Terlihat dari penyampaian pengalaman kehidupan pribadinya yang disertai emoticon untuk menunjukkan ekspresinya atas peristiwa tersebut. Followers seakan diposisikan sebagai teman terdekat Jovi yang mendengar keluh kesahnya. Pemilihan kata yang dipelesetkan (sakit kepala=sekong kepeleus), panggilan sayang (love), serta kata "SEE YOU TODAY LOVE!" yang seakan memang ditujukan khusus untuk bertemu dengan orang yang membacanya, juga menjadi bagian dari strategi yang digunakan Jovi untuk membangun hubungan intim dengan followers.

Fokus terhadap pembangunan hubungan intim antara followers dan Jovi dilakukan untuk memperkuat kepercayaan diantara keduanya. Hal ini pada akhirnya, akan mempermudah Jovi ketika mempromosikan komoditas 
tertentu melalui unggahannya. Mengingat, kecenderungan individu yang hanya tertarik melakukan aktivitas konsumsi setelah memperoleh informasi dari orang terdekatnya (McCaskill dalam Cano, 2019: 14).

Di sisi lain, Anastasia tampak meraih motif ekonomi yang agak berbeda dari Jovi. Selain kerjasama endorsement, Anastasia tampak menargetkan pembentukan kerjasama fashion show dengan beragam desainer dan brand. Motif ini sesuai dengan profesi yang digeluti Anastasia sebagai model. Strategi self-branding yang dijalankannya pun cenderung berbeda. Alih-alih daripada membangun intimacy, Anastasia justru memfokuskan self-brandingnya pada visualitas profesionalitasnya di dunia modelling.

Pada hampir seluruh kontennya, Anastasia tampak menonjolkan konstruksi tubuhnya yang telah disesuaikan dengan standarisasi model androgini. Terlihat pada gambar 2, Anastasia memperlihatkan bahu bidang dan tegap, serta tubuh ramping di balik kemeja hitam yang dikenakannya. Kemeja longgar yang menyembunyikan bentuk payudara dan lekuk tubuhnya, dimanfaatkan Anastasia untuk memperlihatkan fleksibilitas tubuhnya dalam mengenakan fashion apapun. Hal ini dikarenakan, pengelolaan tubuh ini tidak menonjolkan kesan feminin atau maskulin, yang membuatnya fleksibel mengenakan fashion apapun tanpa terbatas pada gender tertentu. Pengambilan gambar secara low angle juga memperlihatkan kakinya yang jenjang untuk menunjukkan kemampuan dirinya dalam menonjolkan kelebihan busana pada tubuhnya secara maksimal. Kemampuan yang penting dimiliki oleh seorang model ketika berjalan di atas catwalk. Anastasia juga memperlihatkan kemampuannya yang satu ini melalui gesture tangannya menyentuh pelipis saat duduk bersandar di sofa, dengan posisi kaki menyilang agak mengangkang. Ekspresi dan gesture yang terkesan santai maupun maskulin ini memaksimalkan kesan maskulinitas dan menampilkan atribut fashion yang dikenakannya dengan sempurna. Profesionalitas di dunia modelling juga diperlihatkan Anastasia melalui unggahan foto pengalamannya terlibat dalam fashion show di akun Instagramnya dan citra dari desainer dan brand terkait. Memanfaatkan fitur tag, mention, serta hashtag, Anastasia meningkatkan kredibilitas dirinya melalui citra brand, desainer, fotografer, makeup artist, dan pihak lain yang dihubungkan dengan fitur-fitur ini.

Di samping itu, tidak sebatas ekspresi, repetisinya dalam mendominasi tubuh dengan atribut dan gesture maskulin juga digunakan Anastasia untuk membuka peluang ekonomi lainnya. Dalam hal ini, peluang masuk ke dunia fashion unisex dan laki-laki, baik kerjasama endorsement maupun fashion show. Pengadopsian gaya kkotminam juga menjadi salah satu strateginya untuk menunjukkan fleksibilitas dirinya di dunia fashion, di mana ia dapat menampilkan gaya yang fashionable tanpa terpaku pada gender tertentu. Dari hal ini dapat dilihat bahwa Jovi dan Anastasia menjalin mutual relationship dan berbagi keuntungan melalui performativitas androgininya.

\section{SIMPULAN}

Fleksibilitas Jovi dan Anastasia dalam melakukan performativitas identitas androgininya menunjukkan sifat cair dalam konstruksi gender sebagaimana dikatakan Butler dalam bukunya Gender Trouble (1999). Melalui performativitas androgininya Jovi dan Anastasia membuktikan, identitas gender dapat diubah seiring perubahan penandaan jasmani pada tubuhnya secara berulang dalam kurun waktu tertentu (Butler, 1988:523). Hal yang berlawanan dengan norma gender konvensional yang memandang gender sebagai hal yang stabil dan tidak dapat diubah. Pergerakan dinamis antara dua polar gender yang dilakukan Jovi dan Anastasia ini kemudian menjadi bentuk gender acts yang secara subversif menggoyahkan norma gender konvensional tersebut.

Pada praktiknya, Jovi dan Anastasia juga tahu benar dengan arena yang dimasukinya, berkaitan dengan bagaimana kuatnya norma gender konvensional di masyarakat. Keduanya tampak memanfaatkan multimodalitas yang ditawarkan Instagram dan memainkan atribut fashion yang ada sedemikian rupa untuk 
menjadi media yang menunjukkan identitas androgini dan membuat dirinya diterima secara halus oleh masyarakat. Dengan menunjukkan identitas gender yang berseberangan dengan norma gender konvensional ini, bukannya memperoleh pandangan negatif dan dikucilkan, Jovi dan Anastasia justru memperoleh popularitas. Dalam hal ini, keduanya menjadi role model dalam dunia fashion, sekaligus berbagi keuntungan ekonomi dengan industri dari performativitas androgini yang berlawanan dengan gender konvensional tersebut.

\section{DAFTAR PUSTAKA}

Abby Gina, A. S. (2019). Personal Experiences of Women Surviving Breast Cancer as a Confrontation of the Meaning of the Women's Body. Jurnal Perempuan, 221-232

Adhiguna, J. (n.d.). Retrieved from Instagram: https://www.instagram. com/joviadhiguna/

Andrzej Galbarczyk, A. Z. (2017). Tattooed men: Healthy bad boys and goodlooking competitors. Personality and Individual Differences, 122-125.

Barker, C. (2014). Kamus Kajian Budaya. Yogyakarta: Kanisius.

Bem, S. (1978). Bem sex-role inventory. Palo Alto: CA: Consulting Psychologists Press.

Budiawan, B. I. (2018). Hamparan Wacana: Dari Praktik Ideologi, Media HIngga Kritik Poskolonial. Yogyakarta: Penerbit Ombak.

Butler, J. (1988). Performative Acts and Gender Constitution: An Essay in Phenomenology and Feminist Theory. Theatre Journal. Vol 40. No. 4, 519-531.

Butler, J. (1999). Gender Trouble: Feminism and the Subversion of Identity. New York: Routledge.

Cano, M. A. (2019). Instagram \& Beauty Micro-Influencers: Strategies of Self
Presentation Used for Personal Brand Development . Eugene: University of Oregon.

Edgar Gomez Cruz, H. T. (2015). Selfies Beyond Self-Representation: the (theoritical) $f(r)$ ictions of a practice. Journal of Aesthetics \& Culture, 2-8.

Friederike Eyssel, F. H. (2012). (S)he's Got the Look: Gender Stereotyping of Robots. Journal of Applied Social Psychology, 1-18.

Hall, S. (2009). Representation: Cultural Representations and Signifying Practices: The Spectacle of 'The Other'. London: SAGE Publication.

Jajang A. Rohmana, E. (2014). Perempuan dan Kearifan Lokal: Performativitas Perempuan dalam Ritual Adat Sunda. Musawa, 151-165.

Kurnia, N. (2004). Representasi Maskulinitas dalam Iklan. Jurnal Ilmu Sosial dan Ilmu Politik, Volume 8, Nomor I, 17-36.

Lie, A. (n.d.). Retrieved from Instagram: https:/ / www.instagram.com/ anastliee/

Marlene Kollmayer, A. P. (2018). Breaking Away From the Male Stereotype os a Specialist: Gendered Language Affects Performance in a Thinking Task. Front. Psychol.

Pérez-Sabater, C. (2017). Emoticons in relational writing practices on WhatsApp: Some reflections on gender. In $P$. BouFranch \& P. Garcés-Conejos Blitvich (Eds.) Analyzing Digital Discourse: New Insights and Future Directions (chapter 7.). Switzerland: Palgrave Macmillan.

Rettberg, J. W. (2017). Self-Representation in Social Media. 1-27.

Westley, H. (2016). Reading The Self in Selfies. Comparative Critical Studies, 371-390.

Wilson, E. (2003). Adorned in Dreams: Fashion and Modernity. London: I.B. Taurus. 